\title{
Molecular Analysis of Retroviral Transduction in Chronic Myelogenous Leukemia
}

\author{
DAVID CLAXTON, ${ }^{1}$ SOON-PAL SUH, ${ }^{1}$ MARYLYNNE FILACCIO,${ }^{1}$ DEBRA ELLERSON,${ }^{1}$ \\ EUGENIA GAOZZA, ${ }^{1}$ BORJE ANDERSSON, ${ }^{1}$ MALCOLM BRENNER,${ }^{3}$ CHRISTOPHER READING, ${ }^{1}$ \\ ANDREW FEINBERG,${ }^{5}$ ROBERT MOEN,${ }^{4}$ JOHN BELMONT,${ }^{6}$ KATERI MOORE,${ }^{6}$ MOSHE TALPAZ, ${ }^{2}$ \\ HAGOP KANTARJIAN, ${ }^{1}$ and ALBERT DEISSEROTH ${ }^{1}$
}

\begin{abstract}
We have developed a polymerase chain reaction (PCR) assay for detection of integrated retroviral transgenomes containing the neo $\mathbf{G 4 1 8}$ resistance gene in colonies (40 cells or more) grown in $\mathbf{G 4 1 8}$ selection after exposure to the neo-positive retrovirus LNL6. This assay also provides for simultaneous characterization of these colonies as belonging to a chronic myelogenous leukemic ( $b c r-a b l$ positive) or nonleukemic population (bcr-abl negative). Using these techniques, we assessed transduction of the LNL6 retrovirus into the normal and leukemic cells of a blast-crisis chronic myelogenous leukemia (CML) patient. This work was designed to support the use of the LNL6 retroviral marker to help identify the origin of relapse after autologous marrow infusion. The data from these experiments show that the majority of CML blast crisis cells that, following exposure to the LNL6 virus, produce colonies under rigorous G418 selection are indeed transduced by the virus, as shown by the presence of the neo retroviral gene. Most of these colonies are also shown to be leukemic by PCR detection of the bcr-abl RNA. This demonstrates the feasibility of the study of CML marrow for retroviral marking. These procedures will be of use in establishing if relapse arises from leukemic blasts which contaminate purged autologous bone marrow infused following intensive therapy for leukemia.
\end{abstract}

\section{OVERVIEW SUMMARY}

A human gene transfer clinical protocol has been approved by the RAC and the FDA in which purged remission marrow cells of adult patients suffering from chronic myelogenous leukemia are marked with the retroviral vector LNL6 prior to re-infusion into the patient at the time of relapse (see this issue, pp. 359-376). Claxton et al. provide here a portion of the data that was used to obtain approval for this protocol.

\section{INTRODUCTION}

\footnotetext{
NTENSIVE THERAPY followed by allogeneic bone marrow transplantation has resulted in long-term disease-free survival in leukemias and other malignancies in which the outlook is poor with conventional therapy alone (Champlin and Gale, 1991). Autologous bone marrow transplantation is also under study at many centers as a method to support intensive therapy in the majority of patients who do not have HLA identical sibling donors or who are ineligible for allografts for medical
}

\footnotetext{
'Department of Hematology and the 'Department of Clinical Immunology and Biological Therapy, The University of Texas M.D. Anderson Cancer Center, Houston, TX 77030.

${ }^{3}$ St. Jude Children's Research Hospital, Memphis, TN 38101

${ }^{4}$ Genetic Therapy, Inc., Gaithersburg, MD 20878. ${ }^{5}$ University of Michigan, Ann Arbor, MI 48109

${ }^{6}$ Baylor College of Medicine, Houston, TX 77030.
} 
reasons (Dicke et al., 1991). Unfortunately, relapses occur in many leukemia patients following treatment with intensive therapy and autologous bone marrow transplantation for advanced diseases. These relapses may ar ise from viable leukemic cells present in the transplanted marrow following in vitro purging or from a systemic tumor that has survived the conditioning regimen used prior to transplantation.

Chronic myelogenous leukemia (CML) most frequently affects individuals in the fifth and sixth decades of life in which patients are ineligible for allografts (Strife and Clarkson, 1990). For this reason, autologous transplantation has been explored as therapy in various disease stages of CML. The vast majority of CML patients given intensive therapy and autografts eventually relapse and succumb to their disease (Brito-Babapulle et al., 1987; Kantarjian et al., 1991). In an attempt to identify the source of these relapses, and to assist in the evaluation of purging procedures designed to remove leukemia cells from autologous marrow, we have proposed to use the safety-modified vector LNL6 to mark marrow cells harvested for autologous bone marrow transplantation in the second chronic phase of CML. We intend to study the relapsing cells for the integration of the selectable transgene neo. If the neo gene is present at the time of relapse, we will conclude that at least a portion of the relapse arose from leukemia cells contaminating the infused marrow.

A substantial body of knowledge has accumulated concerning the molecular and cellular biology of CML (Strife and Clarkson, 1990). In particular, culture systems have been developed in which colonies of leukemic and normal cells can be grown, and polymerase chain reaction (PCR) assays are available which can detect the neoplastic genotype in very small numbers of cell. The successful study of CML relapse after transplantation of LNL6-marked marrow requires the identification of both the neo viral transgene and the CML-specific $b c r-a b l$ transcript from the same 40 cell hematopoietic colony. In this paper, the development of such a dual PCR assay is described. Its use in the study of CML blast crisis marrow cells marked with LNL6 and subsequently propagated in vitro as colonies is documented. It has further been demonstrated that the LNL6 vector becomes integrated into CML colony-forming cells, which are then selectable on the basis of G418 resistance.

\section{MATERIALS AND METHODS}

\section{Isolation of marrow mononuclear cells}

Cells were collected from the peripheral blood by continuous flow centrifugation as an incidental specimen from a regularly scheduled therapeutic procedure which was conducted under a protocol approved by the Human Subjects Committee of The University of Texas M.D. Anderson Cancer Center. FicollHypaque discontinuous gradient centrifugation was used to separate mononuclear cells for exposure to virus. The nucleated cells were concentrated to $10^{8}$ nucleated cells/cc and then cryopreserved. When needed, cells were thawed into tissue culture medium (IMDM) supplemented with $10 \%$ fetal bovine serum (FBS). Cells were diluted to $5 \times 10^{5} / \mathrm{ml}$ in IMDM with $10 \%$ FBS containing stem cell factor $200 \mathrm{ng} / \mathrm{ml}$, interleukin 3 (IL-3) $1,000 \mathrm{units} / \mathrm{ml}$, and granulocyte-macrophage colony-stimulat- ing factor (GM-CSF) 1,000 units $/ \mathrm{ml}$, and incubated at $37^{\circ} \mathrm{C}$ in $5 \% \mathrm{CO}_{2}$ for $24 \mathrm{hr}$. Cells were then counted and resuspended at $10^{6}$ cells $/ \mathrm{ml}$ in conditioned medium from the retroviral producer cell line PA317 LNL6. This supernatant contains the LNL6 virus (Bender et al., 1987), a safety-modified variant of the N2 vector developed by A.D. Miller. This vector supernatant was provided by Genetic Therapy, Inc., and had a titer of $2-5 \times 10^{5} \mathrm{cfu} / \mathrm{ml}$. The ratio of virus to nucleated cell was 10 cfu per nucleated cell. The virus was incubated with these cells for $2 \mathrm{hr}$ in the presence of protamine sulfate at a concentration of $4 \mu \mathrm{g} / \mathrm{cc}$. Following an additional $6 \mathrm{hr}$ of incubation with the LNL6 vector, the cells were washed three times with centrifugation and then incubated in methylcellulose at a concentration of $1 \times 10^{5}$ nucleated cells/cc. Terry Fox Cancer Center methylcellulose culture medium (cat \#HCC-4431) was used for colony growth. Colonies were counted at 7-14 days, with and without G418 selection. The concentration of G418 varied from 1.0 to $1.4 \mathrm{mg} / \mathrm{ml}$. The frequency of acquisition of G418-resistant growth was compared in cells that were exposed or were not exposed to virus.

\section{Control cell lines}

The K562 CML blast crisis line and a subclone transduced with the LNL6 vector, which are designated K562-WT and K562-Neo, respectively, were obtained from Genetic Therapy, Inc. (Gaithersburg, MD). Both were grown in RPMI-1640 supplemented with $10 \%$ FBS. For K562-Neo, G418 $0.8 \mathrm{mg} / \mathrm{ml}$ was added. Colonies of K562-WT and K562-Neo were grown in methylcellulose as described for clinically derived samples.

\section{Colony preparation}

At days 9-10 of growth, colonies were isolated and harvested from methylcellulose under microscopic guidance and deposited directly into $100 \mu \mathrm{l}$ of guanidinium buffer (4 M guanidinium isothiocyanate; $25 \mathrm{mM}$ sodium citrate, $\mathrm{pH} 7.0$; $0.5 \%$ sarcosyl; $0.1 M, \beta$-mercaptoethanol). These tubes were frozen at $-70^{\circ} \mathrm{C}$ or extracted immediately. For extraction, the following were added sequentially to each tube: $10 \mu$ l of $2 M$ $\mathrm{NaCl}, 100 \mu \mathrm{l}$ phenol (buffered to $\mathrm{pH} 8.0$ ), $20 \mu \mathrm{l}$ of chloroform, and $2 \mu \mathrm{l}$ of total yeast RNA $(10 \mathrm{mg} / \mathrm{ml})$. The contents of the tubes were mixed and placed on ice for $15 \mathrm{~min}$. After a 20-min spin in a microcentrifuge, the aqueous phase was added to 100 $\mu \mathrm{l}$ of isopropanol in another tube. After $1 \mathrm{hr}$ at $-20^{\circ} \mathrm{C}$, tubes were spun for $20 \mathrm{~min}$ in a microcentrifuge and pellets were washed with $70 \%$ EtOH. Pellets were dried (speed vac) for 5-10 min prior to addition of $30 \mu \mathrm{l}$ of reverse transcription (RT) mix. This solution contained: $50 \mathrm{~m} M$ HEPES, pH 8.3, $50 \mathrm{~m} M$ $\mathrm{KCL}, 8 \mathrm{mM} \mathrm{MgCl}{ }_{2}, 10 \mathrm{mM}$ dithiothreitol (DTT), $600 \mathrm{~m} M$ each dNTP, $10 \mathrm{~m} M$ random hexamers (Boehringer Mannheim), 0.8 $\mathrm{U} / \mathrm{nl}$ RNasin (Promega), and $1 \mathrm{U} / \mu \mathrm{l}$ AMV-Reverse transcriptase (Life Sciences). Reverse transcription was carried at $42^{\circ} \mathrm{C}$ for $1 \mathrm{hr}$.

\section{DNA amplification}

The primers used for the bcr-abl (Roth et al., 1989) and neo (Morgan et al., 1990) PCR have previously been described and are shown in Table 1. For $b c r-a b l$, two rounds of amplification 
were performed in a strategy similar to that described by Roth et al. (1989). In round one, $15 \mu \mathrm{l}$ of RT product was added to $15 \mu \mathrm{l}$ of a solution that contained $40 \mathrm{mM} \mathrm{KCl}, 0.01 \%$ gelatin, $200 \mathrm{~m} M$ dNTPs, $1 \mu M$ of each of primer ID and IE, and 0.1 U/ $\mu$ l Taq DNA polymerase (Cetus Corporation). The tubes were cycled at $94^{\circ} \mathrm{C} \times 30 \mathrm{sec}, 72^{\circ} \mathrm{C} \times 1 \mathrm{~min}$ for 35 cycles. For round $2,1 \mu$ l of the round 1 product was added to $49 \mu \mathrm{l}$ of a solution that contained $10 \mathrm{~m} M$ HEPES, pH 8.3, $50 \mathrm{~m} M \mathrm{KCl}$, $1.5 \mathrm{mM} \mathrm{MgCl}, 0.01 \%$ gelatin, $2 \mathrm{mM}$ DTT, $200 \mathrm{~m} M$ each dNTP, $1 \mu M$ primers $2 \mathrm{~A}$ and $2 \mathrm{~B}$, and $0.1 \mathrm{U} / \mu \mathrm{l}$ Taq DNA polymerase. The conditions for thermal amplification for round 2 were as used in round one. The positioning of primers is as schematically shown in Fig. 1 and as previously described (Roth et al., 1989). For neo amplification, only one round of amplification was used. RT product, $15 \mu \mathrm{l}$, was added to $15 \mu \mathrm{l}$ of $67 \mathrm{~m} M$ Tris, $\mathrm{pH} 8.8,6.7 \mathrm{mM} \mathrm{MgCl}_{2}, 170 \mu \mathrm{g} / \mathrm{ml} \mathrm{BSA}, 16.6$ $\mathrm{mM}\left(\mathrm{N}_{4} \mathrm{H}\right)_{2} \mathrm{SO}_{4}, 1.5 \mathrm{~m} M$ dNTPs, $2 \mu M$ of primers Neo 1 and Neo 5, $0.1 \mathrm{U} / \mu \mathrm{l}$ Taq DNA polymerase, and 20\% DMSO. The tubes were cycled 35 times through $94^{\circ} \mathrm{C} \times 30 \mathrm{sec}, 50^{\circ} \mathrm{C} \times 1$ min, and $72^{\circ} \mathrm{C} \times 2 \mathrm{~min}$. Each colony was thus assayed for $b c r-a b l$ and neo. PCR products $(15 \mu \mathrm{l})$ were run on agarose gels
( $3 \%$ for $b c r-a b l, 2 \%$ for neo) and stained with ethidium bromide.

\section{RESULTS}

The CML blast crisis cell line K562 was used for the development of the dual PCR assay. This Philadelphia chromosome ( $\mathrm{Ph}$ )-positive line was available to us in both a native (wildtype) and transduced with the LNL6 retrovirus (Neo). We found that both cell lines grew well in the same methylcellulose assay system used for growth of normal and malignant hematopoietic progenitors. The colonies of the K562 cells that grew in this medium were picked, the RNA extracted, and the $b c r$-abl mRNA was amplified under the conditions outlined above using the schema shown in Fig. 1. The products of the PCR amplification of individual K562 colonies grown in this way are shown in Fig. 2. K562 colonies reproducibly showed amplification of the expected 298-bp product. This corresponds to the K28 fusion cDNA described by Shtivelman et al. (1986). Using the strategy shown in Fig. 1, the K28 transcript will give

TABle 1. PRIMERS
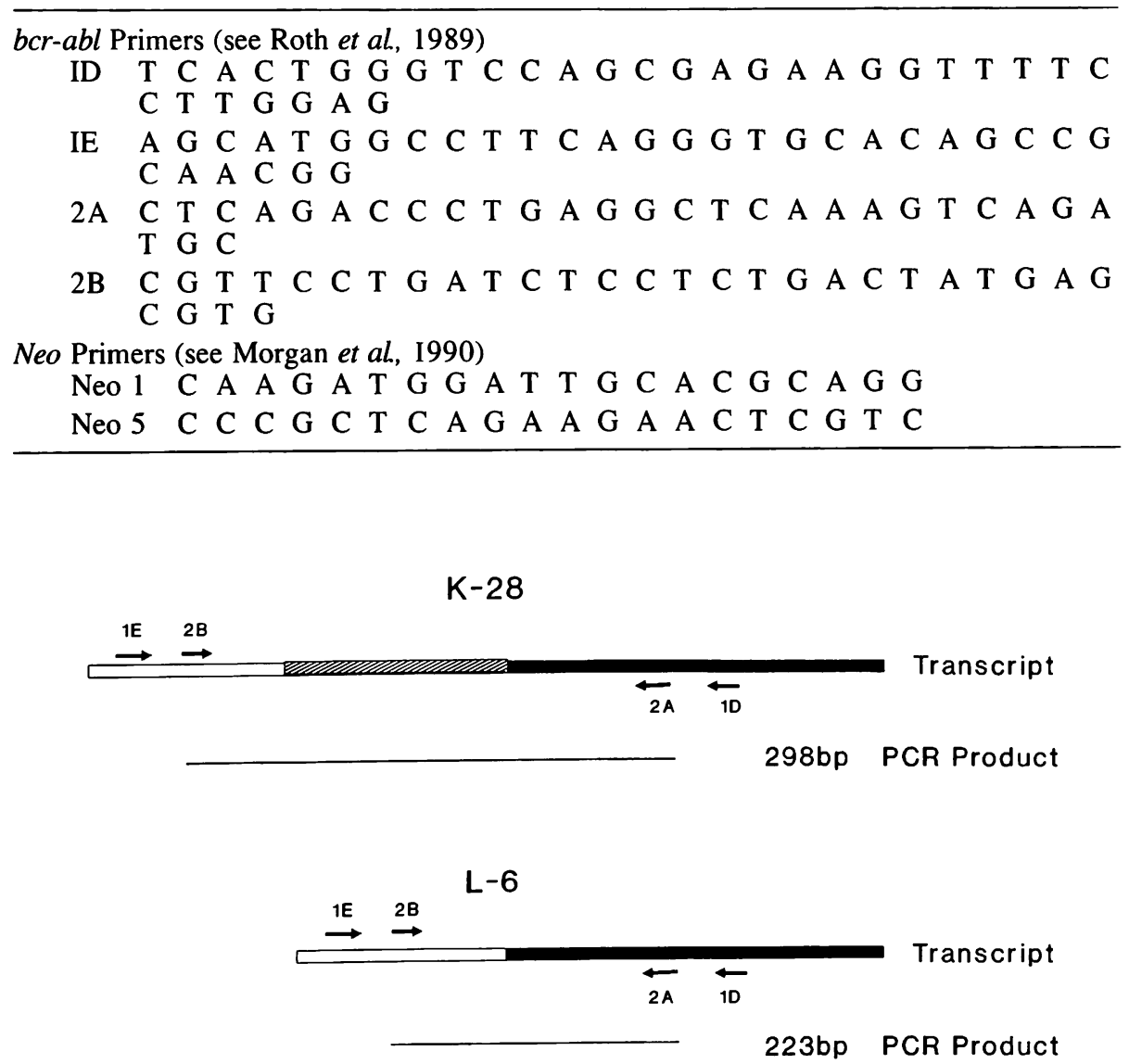

FIG. 1. Schematic diagram of $b c r-a b l$ amplification. $A b l$ sequences are in black. $b c r$ second exon is white. $b c r$ third exon is shaded. The K-28 transcript will give rise to a 298-bp PCR product. The L-6 transcript, which lacks the $b c r$ third exon, will produce a 223-bp product. Note: The size of bcr exon 3 is not drawn to scale and appears larger than its actual size relative to the other exons. 
rise to a 298-bp fragment while the alternate L-6 transcript will produce a 223-bp fragment due to omission of bcr exon 3 (Shtivelman et al., 1986).

We next selected a cryopreserved sample of Ficoll-Hypaqueseparated cells obtained from a patient with CML in myeloid blast crisis. The marrow cells of the patient were incubated in the growth factors SCF, IL-3, and GM-CSF (see Materials and Methods) for $24 \mathrm{hr}$. The cells were then exposed to LNL 6 for 6 hr. The control and LNL6 exposed marrow cells were rinsed and then plated in methylcellulose. The colony growth of control and LNL6 exposed cells on day 7 is shown.in Fig. 3. It should be noted that leukemic cells not exposed to virus showed some growth in concentrations of G418 as high as $1.2 \mathrm{mg} / \mathrm{ml}$, but no growth occurred in $1.4 \mathrm{mg} / \mathrm{ml}$. In contrast, colonies were seen in the virus transduced fractions even at $1.4 \mu \mathrm{g} / \mathrm{ml}$ of G418.

Individual colonies were picked from the methylcellulose on day 10. PCR assays of RNA extracted from these colonies are shown in Fig. 4. For bcr-abl amplification (Fig. 4A), control K562-Neo and K562-wt colonies show the 298-bp band, while the the blank negative control (no cDNA template) shows no amplified product. Five out of eight of the test colonies show a smaller fragment corresponding to the 223-bp L-6 bcr-abl fragment. The neo amplification (Fig. 4B) shows the expected product in the K562-Neo colony and CDNA, but is appropriately negative in the blank and K562-wt reactions. All four of

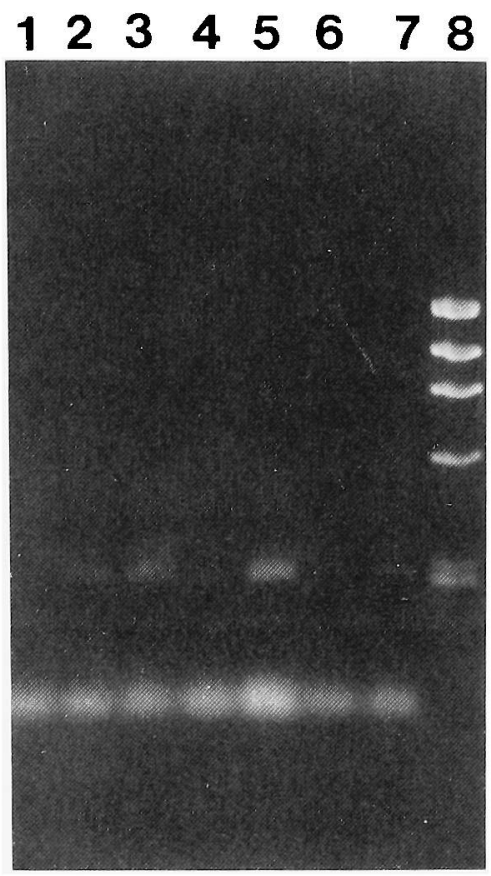

FIG. 2. PCR analysis of colonies of K562 grown in methylcellulose. Cells were grown in methylcellulose as described in Materials and Methods for 7-14 days. Single colonies were harvested and RNA isolated following reverse transcription and sequence amplification with the $b c r-a b l$ primers shown in Table 1. Lane 1 , negative control blank (no cDNA in reaction); lanes 2-7, PCR product from separate K562 colonies; lane 8, molecular weight markers. the test colonies grown in $1.4 \mathrm{mg} / \mathrm{ml}$ of $\mathrm{G} 418$ but none of those from the cultures supplemented with $1.2 \mathrm{mg} / \mathrm{ml}$ of $\mathrm{G} 418$ show neo amplification. Thus, $1.4 \mathrm{mg} / \mathrm{ml}$ of $\mathrm{G} 418$ appears to completely suppress the in vitro growth of cells which have not integrated a functional neo transgenome from LNL6.

\section{DISCUSSION}

We have demonstrated the feasibility of using the LNL6 vector to mark chronic phase and blast crisis marrow cells of CML patients. The PCR assays described in this paper appear useful for distinguishing colonies of cells that arise from the normal or CML marrow cells, and for the identification and enumeration of colonies marked with the LNL6 neo gene. For the lot of G418 used in this study, selection of cells in 1.4 $\mathrm{mg} / \mathrm{ml}$ of G418 suppresses completely the cells which do not contain a functional neo LNL6 transgenome, whereas at lower concentrations of $\mathrm{G} 418$, untransduced colonies appear. Variability in the concentration of G418 required to suppress growth of cells not transduced by virus was encountered in different lots of G418. Therefore, it is recommended that each lot of G418 be characterized with the cells under study for vector transduction.

Much remains to be done in the study of CML using this system. Additional chronic-phase and blast crisis patient samples must be studied to establish the reliability of LNL6 integration into progenitors. The relative efficiency of marking of CML versus normal cells must be established. Efforts will be made to increase the efficiency of marking from the current levels so as to ultimately improve the percentage of marked cells reinfused into patients at transplantation.

We believe that the LNL6 system will facilitate the study of the biology of CML both in vitro and in vivo. It is also hoped that the data arising from these marking experiments will promote the design of better transplantation protocols and ultimately improve the outlook for patients afflicted with CML.

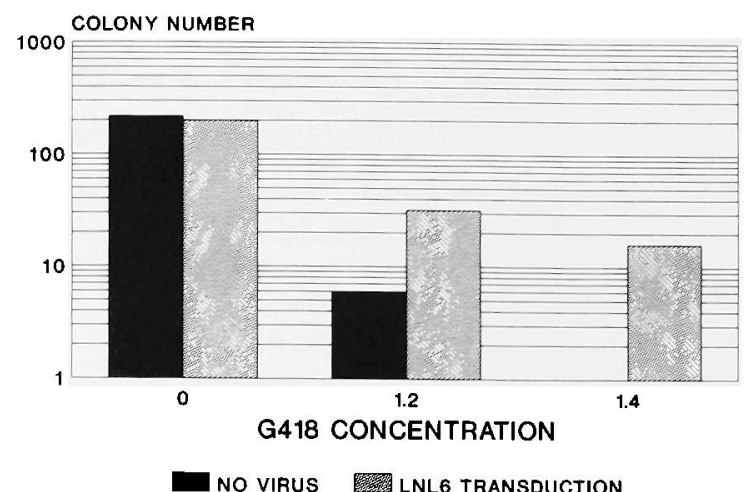

FIG. 3. Frequency of colony growth in G418 methylcellulose assay following exposure to LNL6. Colony counts from day 7 of culture. G418 concentrations are given in $\mathrm{mg} / \mathrm{ml}$. Cells were seeded at $10^{5} / \mathrm{ml}$. Colony number is colonies ( $>40$ cells) per $1-\mathrm{ml}$ dish. Each bar value represents the mean of two dishes in log scale. 


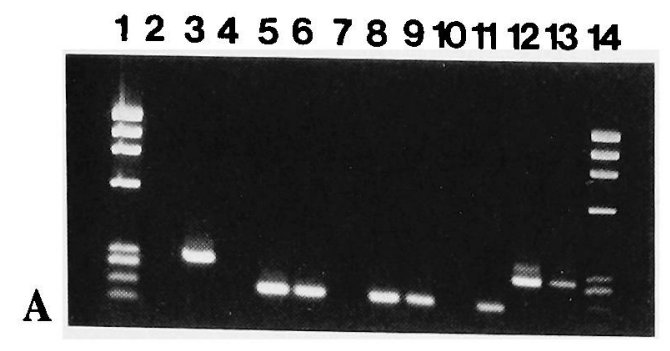

\section{4}

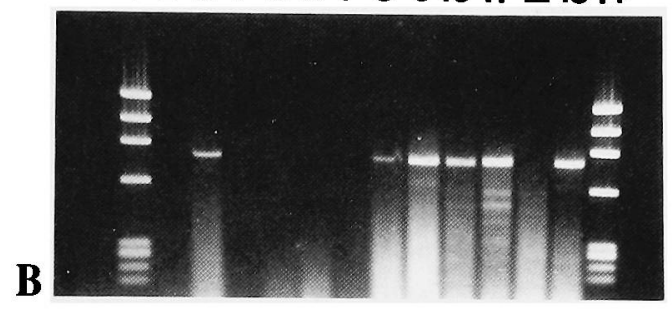

FIG. 4. PCR analysis of colonies of human CML blast crisis after exposure to the LNL6 virus. Primers for the sequence amplification reaction for $b c r-a b l(\mathrm{~A})$ and neo (B) are shown in Table 1 . For both panels, lane 1 contains the molecular weight markers, lane 2 contains the buffer blank, and lane 3 contains the $K 562$ cells that have been transfected with the neo gene as a positive control. Lanes $4-11$ contain amplification products from RNA of colonies of blast crisis CML marrow grown in G418 (Geneticin) at $1.2 \mathrm{mg} / \mathrm{ml}$ (lanes $4-7$ ) and $1.4 \mathrm{mg} / \mathrm{ml}$ (lanes 8-11). Lane 12 is a colony from K562 cells that have not been transfected with the neo gene, and lane 13 contains the products from K562 cells transfected with neo. Lane 14 contains molecular weight markers. As shown in Fig. 3, the 1.4 $\mathrm{mg} / \mathrm{ml}$ of Geneticin is adequate for suppression of virus unexposed cells but $1.2 \mathrm{mg} / \mathrm{ml}$ is not.

\section{ACKNOWLEDGMENTS}

The authors recognize support to Albert Deisseroth from the National Institutes of Health (PO1 CA49639-01A1), the American Cancer Society (IM-580), the Ladies' Leukemia League of Louisiana, the Sid Richardson Foundation, the Gillson-Longenbaugh Foundation, the Bush Leukemia Fund, and the M.D. Anderson Chair for Cancer Treatment and Research. The authors acknowledge a gift of kit ligand, IL-3, and GM-CSF from the Immunex Research and Development Corporation, and a kit ligand from Amgen Biologicals. Many thanks to Rosemarie Lauzon for editorial assistance.

\section{REFERENCES}

BENDER, M.A., PALMER, T.D., GELINAS, R.E., and MILLER, A.D. (1987). Evidence that the packaging signal of Moloney murine leukemia virus extends into the gag region. J. Virol. 61, I639-1646. BRITO-BABAPULLE, F., APPERLEY, J.F., RASSOOL, F., GUO, A.-P., DOWDING, C., and GOLDMAN, J.M. (1987). Complete remission after autografting for chronic myeloid leukemia. Leukemia Res. 11, 1115-1117.

CHAMPLIN, R.E., and GALE, R.P. (1991). New strategies in bone marrow transplantation. UCLA Symp. Mol. Cell. Biol. 137, 163171.

DICKE, K.A., ARMITAGE, J.O., and DICKE-EVINGER, M.J. (1991). "Autologous Bone Marrow Transplantation, Proceedings of the Fifth International Symposium." Omaha, Nebraska.

KANTARJIAN, H., TALPAZ, M., LEMAISTRE, C.F., SPINOLO, J., SPITZER, G., YAU, J., DICKE, K., JAGANNATH, S., and DEISSEROTH, A. (1991). Intensive combination chemotherapy and autologous bone marrow transplantation leads to the reappearance of Philadelphia chromosome-negative cells in chronic myelogenous leukemia. Cancer 67, 2959-2965.

MORGAN, R.A., CORNETTA, K., and ANDERSON, W.F. (1990). Applications of the polymerase chain reaction in retroviral-mediated gene transfer and the analysis of gene-marked human TIL cells. Hum. Gene Ther. 1, 135-149.

ROTH, M.S., ANTIN. J.H., BINGHAM, E.L., and GINSBURG, D. (1989). Detection of Philadelphia Chromosome Positive cells by the polymerase chain reaction following bone marrow transplantation for chronic myelogenous leukemia. Blood 74, 882-885.

SHTIVELMAN, E., LIFSHITZ, B., GALE, R.P., ROE, B.A., and CANAANI, E. (1986). Alternative splicing of RNAs transcribed from the human abl gene and from the bcr-abl fused gene. Cell 47, 277-284

STRIFE, A., and CLARKSON, B. (1990). Introduction to the biologi$\mathrm{cal}$ and clinical understanding of chronic myelogenous leukemia. In Chronic Myelogenous Leukemia: Molecular Approaches to Research and Therapy. A.B. Deisseroth and R. Arlinghaus, eds. (Marcel Dekker, Inc., New York) pp. 1-90.

Address reprint requests to: Dr. Albert B. Deisseroth Box 24

Department of Hematology 1515 Holcombe Boulevard Houston, TX 77030

Received for publication July 17, 1991; accepted after revision October 1, 1991. 
This article has been cited by:

1. Martin K\&ouml;rbling. 1995. Blood stem cell transplantation and gene therapy of cancer. Stem Cells 13:S3, 106-113. [CrossRef] 